\title{
THE STRATEGIC DIMENSION OF THE PUBLIC HEALTH SECTOR IN THE GLOBAL AGE. THE NEXUS BETWEEN PUBLIC HEALTH AND NATIONAL SECURITY
}

\author{
Anca DINICU \\ "Nicolae Bălcescu" Land Forces Academy, Sibiu, Romania \\ anca_dinicu@yahoo.com
}

\begin{abstract}
Although the health sector is a great contributor to the well-being status of every individual and community as a whole, and it is recognized that good health supports the economy, the idea of connecting it with the national security was not very much promoted by the public policymakers, nor by the academics. Over the last three decades, not only that the situation has started to change, but even the concept of health security has gained acceptance and attractiveness. Nevertheless, there is a great debate in theory and practice concerning the real meaning of the concept and the way of understanding it by the professionals from different domains connected with the public health sector. Not to mention that its importance is brought into discussion mainly in times of crisis and the disagreement regarding its content and scope is much deeper between developed and developing countries. This paper proposes to make the necessary distinction between the concepts that constitute the foundation of the specific analysis, but without treating them in a separate way. Also, by dealing with the concept of health security, it aims at highlighting the role of government in the process and last, but not least, to emphasize the need of international cooperation in the global age.
\end{abstract}

KEYWORDS: public health, health security, security, development, World Health Organization.

\section{Introduction}

After the end of the Cold War and given the concrete reality of a world about to become multipolar, when maintaining the national security was no longer an almost exclusively military operation, a group of researchers, led by Professor Barry Buzan, launched the idea of a sectoral approach of the security. Specifically, five sectors were considered: military, economic, societal, political and environmental (Buzan, Wæver \& de Wilde, 2011). It was a major change of the international relations analysis, and an impulse to reconsider the security issue in line with the obvious changes suffered by the national and international politics and security. Gradually, the conceptual development of security has gone further so that the multidimensional approach has constantly launched debates about how different fields of activity could have consequences over the evolution of the national security. The medical sector did not benefit the same interest at the academic and political level and when finally it became subject of analysis, the economic, social or environmental aspects connected with the health issue prevailed in 
front of it. The medical problems were treated in a tangential way, while a comprehensive approach would have been desirable.

\section{Methodology}

The paper aims to establish the relationship between health issues and security, especially at the national level, and to underline the various approaches concerning health security. The paper was written based on:

- A literature review relevant for dealing with security, health and globalization issues and other related topics.

- Empirical research based on observation.

\section{Framing the Health Sector}

\subsection{Conceptual Clarification}

According to the Constitution of the World Health Organization, "Health is a state of complete physical, mental and social well-being and not merely the absence of disease or infirmity." (World Health Organization, 2006). Although a short definition, it is quite inclusive because while most of us consider health by taking in consideration especially the physical sanity and, lately, the mental one, it also includes the social well-being which is mainly a subject of scientific analysis than a matter of self-awareness coming from ordinary people. But even so, this approach is not very helpful for the present analytical endeavour as long as it is not made from the security perspective. The idea is to "slice" the concept of public health and then to "fit" it into the national mechanism that supports a state's prosperity and safety.

Yet, public health seems to be a broad concept as it has different understanding for different people: it is a profession, a science, a system. Even so, a definition of the public health given in 1920 by CharlesEdward A. Winslow, an American public health theoretician, is still considered valid today probably due to its comprehensive approach: it is "The science and the art of preventing disease, prolonging life, and promoting physical health and efficiency through organized community efforts for the sanitation of the environment, the control of community infections, the education of the individual in principals of personal hygiene, the organization of medical and nursing services for the early diagnosis and preventive treatment of disease, and the development of social machinery which will ensure to every individual in the community a standard of living adequate for the maintenance of health" (Schneider, 2017, p. 4).

An important distinction should be made between public health and healthcare, the second one distinctively aiming at preservation or improvement the health by prevention, treatment and healing physical and mental injuries and deterioration. The differences between these two are also obvious when it comes to professionals. Thus, if in the case of healthcare we are talking about physicians and physicians associates, when we approach public health, in addition to those mentioned above, we encounter scientists and researchers, social workers, community planners and public policymakers.

Public health is a domain that implies the application of knowledge from different other fields, among them being biology and anthropology, engineering and computer science, psychology and sociology, education and industry, business and public policy, and last but not least medicine. Moreover, while the healthcare (the medical practice) views individuals as patients, the public health picture community as subject of interest. If the first is about treatment, the second is about prevention done by medicine helped and supported by a large range of professionals from different fields of activity. According to the same logic, the first is based on the relationship between the medical doctor and the patient, while the second is built on the relationship established between government and community (Gostin, 2002). 


\subsection{Importance}

The importance of the public health sector is undeniable and in this respect at least two major arguments can be brought into discussion. The first one is the magnitude of the area of interest by taking into consideration the health of the whole population and every other aspect related or involved with the proper functioning of the sector. The second one is its contribution to maintain, along with the education sector, the social and economic development.

Still, a more challenging issue is the one regarding the strategic dimension of the public health, feature that requires an analysis in close connection with the national security topic. The World Health Organization itself admits, in its Constitution, that "The health of all peoples is fundamental to the attainment of peace and security and is dependent upon the fullest co-operation of individuals and State" (World Health Organization, 2006). Thus, even the specialized global agency responsible for the international public health draws attention to the relationship the public health has with the security question and stresses the need of the state's engagement. Unfortunately, the crucial importance of the public health gains recognition especially in situation of crisis, when natural or manmade disasters happen and epidemics emerge, or when there is a need of providing protection from bioterrorism. Even in the United States of America, the real selfawareness moment of the critical value of the public health in providing safety and enforcing security "came into sharp focus with the events of September 11 and its aftermath" (Gostin, 2002).

Highlighting public health as being of strategic importance arises from admitting it as a sector of critical infrastructure. The issue of critical infrastructure has emerged in the last years as an extremely important element in designing the framework for understanding and preventing the new security threats, at national and international level. If we were to locate on a timeline the moment of awareness of the extraordinary impact of this sector on security, it would be after the end of the Cold War, when security was no longer understood and considered almost exclusively in military terms but, on the contrary, approached from a multidimensional perspective. Critical infrastructures are analyzed in connection to national security due to the impact that these, through a malfunction, can have on national economy and people's lives. The array of the critical infrastructure meanings is reflected in practical terms in the variety of elements that make up the field of critical infrastructure, the diversity having its roots in realities such as: the level of economic development of each state, the emphasis granted by the governments to different fields of activity, and their contribution in ensuring the safe functioning of the society and national economy. Completing the circle, it should be said that the importance of the public health sector as critical infrastructure is given by the critical infrastructures interdependency and is related with the situations of emergency and disaster.

\section{Understanding the Concept of Health Security}

The first duty of a state is to protect its citizens, to provide national security.

Decrypting health security concept is not an easy task if we consider not only its novelty, but also the ambiguity of defining and using it by the various stakeholders as long as "understanding" the problem is made according to their economic and political interest, fact that leads to a lack of clarity concerning the vision, strategic objectives and tools.

Most often, the approach of the health security issue starts from human security issues, which has proven to be an adequate analytical framework for identifying and addressing cutting across sectors problems 
in order to encourage nations to create a world free from fear, want and indignity.

The intellectual exercises of redefining security in line with redefining the international context created after the end of the Cold War, including shifting the analysis to non-state security beneficiaries or other actors involved in the security process than the state, led to the strong assertion of the human security concept. A multifacets concept, human security has the capacity of bringing in focus a variety of threats to human existence such as: poverty, environmental degradation, starvation, lack of health care and so on. According to 1994 Human Development Report, which was very specific in recognizing the seven dimensions of human security (economic, health, personal, political, food, environmental, community), underlined that appreciating "the security of people's livelihoods might apply a human security approach" (Gomez \& Gasper, 2013).

Recognizing that the state remains the main security provider, the experts that embrace this theory consider that the national security is not a sufficient and satisfactory condition so as human welfare to be gained and maintained. Although true that the individuals along with the community they belong to should be considered as referent, not only the state itself, putting these actors on the same level of analysis could be controversial. One hand, there is the state-centred approach to security (national security), on the other hand, is the people-centred approach (human security and health security as defined by the concept of human security). The last one involves the manner of understanding and solving the conflict by a multi-stacker engagement, and implies programmes to be planned and implemented by a lot of actors, including the state. It is hard to believe that a state would think differently when it comes to consider national security and human security concerning individuals and communities. Besides this aspect, the concept of human security is necessarily linked with that of a conflict and societal violence. As a consequence, it is unlikely to be related with the individuals belonging to developed states. Furthermore, can we talk about security when dealing with a state turned apart by conflict? In theory, yes, but in practice, when analyzing the real situation, no, because it is the insecurity we are interested in.

Another important obstacle in creating a common acceptable framework for dealing with a unified concept of health security is the economic and social development, obviously marked by the level of democratization not of the society, but of the political establishment and decision making process. Moreover, it is a truism that the international system's architecture main feature is power, power of state.

Health issues related to security is not a new approach, even though the main aspects that gained state's interest were in relation with the military, hoe disease could affect military capacity and operations. What is new is the concept or better said all the efforts focused on theorizing it. At a first glance, health security may refer to aspects concerning personal health, but in this case the analysis is transferred on the field of healthcare. What is indeed important for the health security is the public health system which also includes healthcare services. In this case, the referent subject is the community or the society at large and the issues that may be put under debate when picturing the level of a state's health security are: health expenditures, quality of health services, soundness of legislation, level of innovation, state's readiness and response to medical crisis, quality of environment, and all other aspects, no matter the domain they come from, and regardless if they can benefit or can endanger the public health. 
Aware of the importance of the public health for ensuring the proper functioning of their societies and for guaranteeing national security, states understood the need to formalize this issue, by including specific provisions in constitutions and / or national security strategies. Thus:

- The United States of America: Will " ... detect and contain biothreats at their source ... encourage other countries to invest in basic health care systems and to strengthen global health security ... to prevent infectious disease outbreaks ... work with partners to ensure that laboratories that handle dangerous pathogens have in place safety and security measures ... implement public health containment measures to limit the spread of disease ... support public health efforts ... assess risk across six key areas [health included] ... support food security and health programs that save lives and address the root cause of hunger and disease" (White House, 2017). It is to be noticed that the expression "health security" linked with national security at home is not mentioned by the document, like is the case of "food security". Instead, it introduces in discussion the issue of "health security" linked with international security and politics, and probably with national security abroad which would emphasize America's interest in global affairs according to its global status.

- Italy: "The Republic safeguards health as a fundamental right of the individual and as a collective interest, and guarantees free medical care to the indigent." (Constitution of the Italian Republic, Article 32) (Senato della Repubblica).

- Spain: Considers epidemics and pandemics as challenges to national security (National Security Strategy, 2017, Chapter 4) (National Security Council, 2017).

- Russia: Admitting that health is " $a$ right of every Russian citizen", Moscow links healthcare with ensuring national security by: listing "the strategic national security goals in the area of healthcare and the health of the nation"; acknowledging the threat that large-scale epidemics and pandemic can represent; recognizing "the low effectiveness of the medical insurance system and the low quality of healthcare specialist training and retraining"; underlining the role of preventive medicine and orientation of healthcare; "enhancing the quality and accessibility of medical services"; highlighting the importance of "the effectiveness of state regulation in the area of standardization"; and establishing the means in order to achieve "the resolution of problems of national security in the sphere of healthcare and the health of the nation in the medium and long term" (Russia's National Security Strategy to 2020, 2009) (Center for Security Studies, 2012).

- Romania: Recognizes that protection of health is a right (The Constitution of Romania, Article 34) (Presidential Administration) and among the seven "lines of action and main ways to ensure national security", the health dimension is developed, along with the educational, social and demographic ones (Romania's Defence Strategy, 2015) (Presidential Administration).

To summarize, health is a citizen's right and a main area of action in order to preserve national security. It is an issue that can threat or challenge the national security. Even without specifically using the concept "health security", states manage to understand the importance of health sector for nation developing and surviving, in accordance with their vision about national security, with their national interests and tools of achieving them, and with their capacity of designing the world or just complying with the world order.

The conceptual clarifying of health security is influenced by the essence state gives to national security and by the components of the public health which are also established by the state. 


\section{Connecting Health and Security at the Global Level}

Political globalization has generated not only benefits, but also serious challenges to national security through the velocity and sometimes unpredictability of the events' evolution. The permeable nature of borders, facilitating transnational interactions, would allow (re)emergence of less pleasant experiences for the daily comfort of individuals, the development of societies and, finally, the preservation of national security. In this context must be brought into attention: the increased population mobility, the migration waves, the environmental changes, the spreading of transnational crime and terrorist action, the emerging diseases. Some of them, like the last phenomenon, are not new, and without being related to globalization as it is understood today, were favoured by mobility on which also geographic discoveries or empires' building relied on: the Plague of Justinian which started in 6th century Constantinople and spread throughout the Mediterranean, killing between 30 and 50 million people and precipitating the fall of Byzantine Roman Empire (Than, 2014); the bubonic plague, known as the Black Death, which struck Europe and Asia in the mid-1300s, killing 50 million people [History com. Editors, 2020]; smallpox in North America from European settlers, between 1633-1634, when over 70 percent of the native American population dropped (Healthlinez); or the influenza pandemic in 1918, known as the Spanish Flu, was a global disaster, killing between 20 and 40 million people (Billings, 2005). Nowadays, humankind still has to confront epidemics and pandemics, despite of science progress and all the advantages brought by globalization.

In fact, globalization is for health, as an area of security, "a double-edged sword" (Hough, 2015). It means that globalization is able to generate challenges and threats, but also opportunities which handled properly to help solving the problems. Of course, the solutions are different from case to case and the donors vary from states and international organizations to nongovernmental organizations and private philanthropic persons. Of course, there is a keen need of reaching consensus between these different actors, everyone being focused to achieve its own interest and having a specific understanding of health security in terms of content, objectives and instruments. At the international level, the national interest should be put aside so that the collaborative solutions founded to benefit all. But due to the fact that the international system is still marked by the struggle for power, some actors, mainly states, could have a hidden agenda and so aid and humanitarian interventions to become an excuse of reaching their own security objectives. And perhaps much dangerous is the fact that such actions take place between powerful states, as it seems was the case with Russian COVID-19 aid to Italy, in spring 2020 (Nicolova, 2020).

Nowadays complex global problems need common solutions based on common understanding of the world with everything it encounters. And such an issue is global public health security which, according to the World Health Organization, "is defined as the activities required, both proactive and reactive, to minimize the danger and impact of acute public health events that endanger people's health across geographical regions and international boundaries" (World Health Organization). Of course, these activities should take into account the diversity of states caused by their level of development and be based on solidarity as general framework for solving health emergencies and strengthen weak health system. 


\section{Conclusions}

Good health is a condition for achieving national security and achieving of good health is a result of a common effort undertaken by various actors. Taking into consideration that public health has a constitutional political nature and it claims sound strategies to become a real contributor to a prosperous and safe state, it is obvious that health security is intrinsically bounded to government which has the main responsibility to support public's health.

If during the Cold War, health issue was important for national security especially linked with the military field, nowadays, due to the sectoral approach of security and as an effect of a "flourishing" globalization, public health and national security overlap in a considerable extent.

In the same time, a health problem can be understood as a challenge to security, no matter if national or international, or as a threat. In order to prevent these situations, a better assessment of every public health issue is necessary and a real cooperation among the stake-holders is desired. As a social enterprise, public health should be promoted through policies and strategies capable to deliver health equity and to foster solutions based on cooperation at the international level.

\section{REFERENCES}

Billings, M. (2005). The Influenza Pandemic of 1918, available at: https://virus.stanford.edu/uda/, accessed on 12 May 2020.

Buzan, B., Wæver, O., \& de Wilde, J. (2011). Securitatea. Un nou cadru de analiză. București: CA Publishing.

Center for Security Studies Zurich (2012). Russia's National Security Strategy to 2020, available at: https://css.ethz.ch/en/services/digital-library/publications/publication.html/154915.

Gomez, O. A., \& Gasper, D. (2013). Human Security, available at: http://hdr.undp.org/sites/default/files/human security guidance note r-nhdrs.pdf, accessed on 13 May 2020.

Gostin, L. O. (2002). Public Health Law, Journal of Law, Medicine \& Ethics, Vol. 30, No.2, available at: https://scholarship.law.georgetown.edu/cgi/viewcontent.cgi?article= 2830\&context $=$ facpub , accessed on 12 May 2020.

Healthline. The Most Dangerous Epidemics in U.S. History. A look back, available at: https://www.healthline.com/health/worst-disease-outbreaks-history\#1, accessed on 13 May 2020.

History com. Editors (2020). Black Death, available at: https://www.history.com/ topics/middle-ages/black-death, accessed on 12 May 2020.

Hough, P. (2015). Health and Security, International Security Studies, Theory and Practice. New York: Routledge.

National Security Council (2017). National Security Strategy, available at: https://www.dsn.gob.es/sites/dsn/files/2017 Spanish National Security Strategy 0.pdf, accessed on 13 May 2020.

Nicolova, A. (2020). Russian COVID-19 aid to Italy: PR stunt or covert operation?, available at: https://www.euractiv.com/section/defence-and-security/news/russian-covid-19aid-to-italy-pr-stunt-or-covert-operation/, accessed on 14 May 2020.

Presidential Administration. The Constitution of Romania, available at: https://www.presidency.ro/en/the-constitution-of-romania, accessed on 14 May 2020.

Presidential Administration. Romania's Defence Strategy, available at: https://www.presidency.ro/files/userfiles/National Defense Strategy 2015 - 2019.pdf, accessed on 14 May 2020. 
Schneider, M. J. (2017). Introduction to Public Health. Burlington: Jones \& Barlett Publishers.

Senato della Repubblica. Constitution of the Italian Republic, available at: https://www.wipo.int/edocs/lexdocs/laws/en/it/it037en.pdf, accessed on 12 May 2020.

Than, K. (2014). Two of History's Deadliest Plagues Were Linked, with Implications for Another Outbreak. National Geographic, available at: https://www.nationalgeographic.com/ news/2014/1/140129-justinian-plague-black-death-bacteria-bubonic-pandemic/, accessed on 12 May 2020.

White House (2017). National Security Strategy of the United States of America, available at: https://www.whitehouse.gov/wp-content/uploads/2017/12/NSS-Final-12-182017-0905.pdf, accessed on 14 May 2020.

World Health Organization (2006). The Constitution of the World Health Organization, available at: https://www.who.int/governance/eb/who constitution en.pdf, accessed on 14 May 2020.

World Health Organization. Health Security, available at: https://www.who.int/healthtopics/health-security/\#tab=tab 1, accessed on 14 May 2020. 